\title{
Encapsulated Allogeneic Synovial Membrane Mesenchymal Stem Cells Provide Better Outcomes of Chondral Lesions in Horses
}

\section{Vitor Hugo Santos}

FMVZ UNESP - Botucatu https://orcid.org/0000-0001-5622-9152

João Pedro Hübbe Pfeifer

Universidade Estadual Paulista Julio de Mesquita Filho - Campus de Botucatu

Fernanda de Castro Stievani

Universidade Estadual Paulista Julio de Mesquita Filho - Campus de Botucatu

\section{Gustavo Santos Rosa}

Universidade Estadual Paulista Julio de Mesquita Filho - Campus de Botucatu

\section{Emanuel Vitor Pereira Apolonio}

Universidade Estadual Paulista Julio de Mesquita Filho - Campus de Botucatu

\section{Mariana Correa Rossi}

Universidade Estadual Paulista Julio de Mesquita Filho - Campus de Botucatu

\section{Leonel Vinicius Constantino}

Universidade Estadual de Londrina

\section{Thadeu Rodrigues de Melo}

Universidade Estadual de Londrina

\section{Carlos Eduardo Fonseca-Alves}

Universidade Estadual Paulista Julio de Mesquita Filho - Campus de Botucatu

Ana Liz Garcia Alves ( $\sim$ ana.liz@unesp.br)

Universidade Estadual Paulista Julio de Mesquita Filho - Campus de Botucatu

\section{Research}

Keywords: alginate, bioengineering, horses, immunomodulation, mesenchymal cells.

Posted Date: June 9th, 2021

DOI: https://doi.org/10.21203/rs.3.rs-587036/v1

License: (1) (1) This work is licensed under a Creative Commons Attribution 4.0 International License.

Read Full License 


\section{Abstract}

\section{Background}

Osteoarthritis is the main cause of equine lameness and its treatment remains ineffective. Synovial membrane mesenchymal stem cells ( $\mathrm{SM} M \mathrm{MSC}$ ) provide satisfactory outcomes in joint injuries, mainly due to their immunomodulatory and reparative properties. This study aimed to evaluate the effect of ${ }_{\text {MSMSC, }}$ either encapsulated in alginate hydrogel or free, in chondral lesions of horses.

\section{Methods}

Chondral lesions were surgically induced in medial trochlea of talus of fifteen horses. Animals were treated with PBS, $1 \times 10^{7}$ free ${ }_{S M} M S C$ or $1 \times 10^{7}$ encapsulated $S_{S M}$ MSC. Physical evaluations, lameness scores and synovial fluid analysis were determined (cytological analysis and dosage of IL-1, IL-10, IL-6, INF- $\bigotimes$, TNF $\alpha$, P Substance, Serum Amyloid A, TGF- $\beta$, IGF and PGE2) initially and followed for up to two weeks. Cartilage biopsies were performed 150 days after the induction for histological analysis and immunohistochemistry staining.

\section{Results}

All groups presented inflammation initially. Although free ${ }_{S M}$ MSC showed moderate tissue repair, encapsulated ${ }_{S M} M S C$ modulated inflammation and had the lower grade of inflammation with superior tissue macro and microscopic aspects at the end, while the control group showed fibrosis and poor cartilage appearance. This study suggests better stem cell effectiveness in chondral defects when encapsulated MSCs are used.

\section{Conclusions}

While the absence of treatment perpetuates cartilage degradation, encapsulated ${ }_{S M} M S C$ responded better to the initial inflammation, interacting and modulating the environment through the release of antiinflammatory cytokines. Better outcomes observed in encapsulated MSCs were related to the immuno and physical barrier provided by the alginate hydrogel, allowing a longer period of permanence and interaction between MSCs and the environment.

\section{Introduction}

Osteoarthritis (OA) is the main cause of lameness in horses, leading to poor performance and important economic impacts (1). Even though its etiology is multifactorial, mechanical forces are the major causes of chondral lesions, generating chondrocyte injury and release of proteases that result in chondral fibrillation $(2,3)$. Cell-based therapy and tissue engineering can help to promote better chondral healing, reducing articular damage and pain (4). 
Strategies combining mesenchymal stem cells (MSC), biocompatible scaffolds and bioactive components provide mechanical support and a cell source, in order to contribute to joint repair $(4,5)$. Although several cell sources have been used with positive results, synovial membrane-derived mesenchymal stem cells ( $\mathrm{SM} M \mathrm{MSC}$ ) present high proliferation capacity and chondrogenic differentiation (6). They can also be obtained through minimal invasive techniques (6-9). Treatment of OA using MSC relies on its immunomodulatory and paracrine effect, decreasing lymphocyte activation and releasing several molecules (IL-10, IL 1 ra, TGF- $\beta$ e PGE2) $(5,10,11)$ and growth factors $(12-17)$ involved in the articular repair process. Despite the noticeable benefit tissue engineering brought to orthopedics, some undesired events still remain, especially systemic dispersion (18) and decreased viability after MSC intraarticular injection (19). Thus, recent studies used encapsulated stem cells in joint injuries in aiming to protect, maintain cell viability and stimulate chondrogenic differentiation (19).

The aim of this study was to evaluate the effect of ${ }_{S M} M S C$ encapsulated in alginate hydrogel on immunomodulation and healing of induced tibiotarsal lesions of horses.

\section{Methods}

Fifteen healthy geldings were used in this study, with age between 3 and 8 years and mean weight of $330 \mathrm{~kg}$. Animals were divided into 3 groups of 5 animals each: ${ }_{S M} M S C$ alone (GA), encapsulated ${ }_{S M} M S C$ (GB) and control (GC).

\section{Cell culture and encapsulation}

All the ${ }_{S M} M S C$ were previously characterized and stored in a biobank. Cells were cultured until $1 \times 10^{7}$ SMMSC in third passage (P3), according to the technique described by $(5,20)$. Cells from the encapsulated $S \mathrm{MSC}$ group were resuspended in 1.5\% (w/v) sodium alginate. The mixture was dripped in a gelling solution of $\mathrm{CaCl} 2102 \mathrm{mM}$ using a $10 \mathrm{ml}$ syringe and a $21 \mathrm{G}$ needle in an infusion pump. The drops were maintained within the solution for 10 minutes for the crosslinking reaction and capsule formation. Capsules were washed three times in $\mathrm{NaCl} 0.15 \mathrm{M}$ before the injection.

Cell viability was assessed by trypan blue exclusion method in a Neubauer chamber, after dissolving alginate hydrogel with sodium citrate ${ }^{[1]}$.

\section{Arthroscopic procedure and treatments}

Tibiotarsal joints were submitted to arthroscopy to induce the chondral lesion and the treatment was made at the moment of the surgical procedure.

Thus, arthroscopy was set as the initial moment (0h). Clinical parameters and synovial fluid analyses were performed at time points $0,24,48,96,168$ and $336 \mathrm{~h}$. 
Chondral lesion was made according to the technique described by Mcllwraith (21). In brief, the shaver was used to create the lesion of $15 \mathrm{~mm}$ of diameter (figure 1). A Ferris-Smith forceps was used to remove the hyaline and calcified cartilages without reaching subchondral bone (mean depth of 1.5 - $3.2 \mathrm{~mm}$ ).

All treatments were performed at the initial time, immediately after the induction of chondral lesion. The capsules were injected through the arthroscopic portal using a levine catheter $n$. 20. Free SMMSC were injected diluted in $10 \mathrm{ml}$ of PBS. Control group received only $10 \mathrm{ml}$ of PBS.

\section{Clinical and laboratorial evaluations}

Clinical parameters (physical examination and lameness score) were assessed before the arthrocentesis by two evaluators in a blind manner. Tibiotarsal arthrocentesis was performed in all time points. Synovial fluid immediate analysis included fibrinogen concentration and cytological evaluation (total nucleated cells and differential counting). Stored synovial fluid was used for quantification of IL-1, IL-10, IL-6, INF-区, TNF $\alpha^{[2]}$, P Substance ${ }^{[3]}$, Serum Amyloid $A^{[4]}$, TGF $\beta^{[5]}$, IGF $^{[6]}$ and PGE2 ${ }^{[7]}$ by ELISA assay, following the manufacturer instructions. Absorbance was read at $450 \mathrm{~nm}$ wavelength.

A new arthroscopy was performed after 150 days to observe the macroscopic appearance of the chondral surface in situ and to harvest cartilage for histological analysis and immunohistochemistry for type II collagen. The cartilage aspect was graded according to the International Cartilage Repair Society (ICRS) score, which evaluates cartilage repair, lesion edges integration, macroscopic appearance and general aspect of the repair tissue. This grading was performed blindly by 6 evaluators, after viewing the recorded arthroscopies.

Chondral tissue was harvested and cryopreserved using Tissue-Tek ${ }^{\circledR}$ O.C. T $^{\mathrm{Tm}}{ }^{[8]}$ for histological evaluation (Hematoxylin-Eosin and Toluidine blue stainings), according to the O'DRISCOLL histological score. The evaluators were also uninformed of the experimental groups at the time of evaluation.

Immunohistochemistry (IHC) was performed according to the technique described (22). The peroxidase and 3,3'-diaminobenzidine tetrahydrochloride (DAB) method was used for IHC. Antigen retrieval was performed using citrate buffer $(\mathrm{pH} 6)$ in a pressure cooker ${ }^{[9]}$ and the glass slides were put into the autostainer Dako Cytomation ${ }^{[10]}$ platform. Anti-type II collagen antibody was detected using a mouse secondary monoclonal antibody ${ }^{[11]}$ in a $1 / 200$ dilution. Immunologic staining was performed using Histofine ${ }^{[12]}$ method and the slides were counterstained with hematoxylin. Positive control was pulmonary tissue, whereas negative control was made by not using primary antibody.

All samples were evaluated in bright field microscopy and graded in a semi-quantitative scoring system, where the absence of expression was scored as 0 ; from $1 \%$ to $25 \%$ of positive staining was graded as 1 ; from $26 \%$ to $50 \%$ of positive staining was graded as 2 (weak); from $51 \%$ to $75 \%$ of positive staining was graded as 3 (moderate) and score 4 when more than $75 \%$ cells were stained (strong).

\section{Statistical analysis}


Normality test was performed using Kolmogorov - Smirnov test. In the absence of normality, KruskalWallis test was applied for comparison between groups at the same time points and Friedman test was applied for comparison between time points of each group. Tukey test was performed for comparison between medians using Sigmastat 3.5 software when there was significance.

Correlation between treatments and cytokines is shown in heatmap (pheatmap package), grouping data hierarchically by Euclidean distance and Ward method. The "R" software was used for Pearson correlation coefficient.

Data regarding treatment response was analysed by general linear model ANOVA (GLM) considering the evaluator and the experimental group as constant. In case of significance, mean values were compared by Tukey test.

Descriptive analysis is presented as mean \pm SEM or proportion. Significant difference was considered when $P \leq 0.05$ and tendency towards statistical significance when $P<0.10$.

${ }^{[1]}$ Anticoagulant Acid Citrate Dextrose Solution (ACD-A) - Haemonetics Corporation - Braintree, MA

${ }^{[2]}$ Milliplex Map Kit, Equine cytokine (EQCYTMAG-93K) - EMD Millipore Corporation - Germany.

${ }^{[3]}$ Horse Substance P (SP) Elsa Kit - MYBIOSOURCE - USA.

${ }^{[4]}$ Horse Serum Amyloid A (SAA) Elisa Kit - MYBIOSOURCE - USA.

${ }^{[5]}$ Milliplex Map Kit, TGF beta single plex magnetic bead kit - EMD Millipore Corporation - Germany.

${ }^{[6]}$ Horse IGF-1 (Insulin-like growth factor 1) Elisa Kit- MYBIOSOURCE - USA.

${ }^{[7]}$ PGE2 (Prostaglandin E2) Elisa Kit - Elabscience Blotechnology Inc. - USA.

${ }^{[8]}$ Sakura Finetek Europe B.V. Germany.

${ }^{[9]}$ Pascal ${ }^{\circledR}$; Dako, Carpinteria, CA, USA.

${ }^{[10]}$ Dako, Carpinteria, CA, USA.

${ }^{[11]}$ Sigma Aldrich, Saint Louis, Missouri, USA.

${ }^{[12]}$ 414154F, Nichirei Biosciences, Tokyo, JP.

\section{Results}


Mean count and viability of $\mathrm{SM}_{\mathrm{MSC}}$ in GA was $1.4 \times 10^{7}$ and $98,20 \%$, whereas GB presented $1.5 \times 10^{7}$ and $97,40 \%$, respectively. Each capsule contained approximately $1 \times 10^{5}$ cells (Figure 2 ).

Physical parameters did not vary at any time point, maintaining within physiological range for the species. Lameness scores reached grade $2 / 5$ at $24 \mathrm{~h}$ and $48 \mathrm{~h}$, accompanied by synovial effusion. Both lameness score and effusion decreased to $1 / 5$ after $168 \mathrm{~h}$.

Synovial fluid analysis (Figure 3 ) revealed statistical differences in total nucleated cells (TNC) between $\mathrm{GB}$ and the other groups at $24 \mathrm{~h}$ time point $(\mathrm{P}=0.0473)$. Comparison of the moments within the same group showed a significant increase in TNC at $24 \mathrm{~h}$ in GB, whereas in GA the significant increase remained till 48h $(P=0.002)$.

Neutrophil counting showed a significant increase at time point 24h in GB in relation to the other groups $(P=0.006)$. Within groups, both $G A$ and $G B$ demonstrated significant neutrophil increase at 24 and $48 \mathrm{~h}$ time points $(P<0.001)$.

Lymphocytes count in GB presented a statistical difference at 24h $(P=0.004)$, whereas the increase remained for $48 \mathrm{~h}$ in $\mathrm{GA}(\mathrm{P}=0.009)$ and till $168 \mathrm{~h}$ in the control group $(P=0.015)$.

Macrophages showed a significant increase in all groups initially. However, treated groups presented a sooner decrease observed by the statistical difference between control and treated groups at $96 \mathrm{~h}$ $(P=0.025)$.

Total protein (TP) of both treated groups significantly increased at $24 \mathrm{~h}$, when compared to the initial moment $(P<0.05)$

Values of interleukin-6 (IL-6) only showed statistical differences at $168 \mathrm{~h}$ time point $(\mathrm{P}=0.030)$, where GB presented higher values compared to the control group, but did not differ from the GA

Individually, there was a peak of IL-6 in GA at 48 and $96 \mathrm{~h}(\mathrm{P}=0.003)$, whereas it occurred only at $96 \mathrm{~h}$ in GB $(P=0.004)$. Control group did not present statistically significant differences throughout the time points $(P=0.218)$.

No differences were observed between groups or within the same group in SAA, P substance, PGE2, IL$1 \alpha$, TNF $\alpha$, IGF 1 and TGF $\beta$ ( $P>0.05)$, even though TGF $\beta$ levels remained higher in control group.

It was possible to notice statistical superiority in IL-10 at $24 \mathrm{~h}, 48 \mathrm{~h}$ and $96 \mathrm{~h}$ time points in the GB compared to the initial moment $(P=0.012)$, remaining till the $336 \mathrm{~h}$ time point.

The hierarchical grouping divided treatments into two groups: Control group and treated group (which included both free and encapsulated cells). The variables were divided in four groups: 1: SAA and IGF; 2: TNCC, TP, IFN, TGF, TNF, IL-10, NC and IL-6; 3: MC, LC and IL-1; and 4: SP and PGE2. Encapsulated MSCs were related to higher SAA, IGF, TNCC, TP, IFN- $\gamma$, TGF $\beta$, TNF $\alpha$, IL-10, neutrophil count and IL- 6 values, 
whereas free MSCs leaded to higher IL-1, macrophage and lymphocyte counts, and control group was associated with higher SP and PGE2 levels (Figure 5).

There was a positive correlation between PGE2 and TGF $\beta$ ( $r=0.47)$, IL-1 and IL-10 ( $r=0.96)$, IFN- $\gamma$ and TNF $\alpha(r=0.87)$, IL-10 and IL-6 ( $r=0.37)$, SP and TNF $\alpha(r=0.49)$ and IL- 6 and NC $(r=0.23)$ in GA. GB revealed positive correlation between NC and IL-10 ( $r=0.43)$, IL-10 and IL-6 ( $r=0.32)$, IFN $-\gamma$ and TNF $\alpha(r=0.75)$, IFN and IL-6 $(r=0.23)$, TNF $\alpha$ and IL-10 ( $r=0.38)$, and MC with TNF $\alpha(r=0.19)$. Group control showed positive correlation between IL-6 and IL-10 ( $r=0.77)$ and in IGF with TP $(r=0.44)$. (Figure 6).

Encapsulated MSCs group (GB) presented a better macroscopic appearance, similar to the naive cartilage. On the other hand, it was possible to observe chondral erosions and peripheral detachments in the group of free MSCs (GA). However, no signs of synovitis, fibrillation or erosion were observed in both groups (Figure 8). Control group presented fibrosis with unfilled, friable and eroded areas.

The Global Repair Evaluation (GRE) showed higher scores in the GB when compared to the GC ( $P=0.007)$. The results of all groups are presented in table 1.

Table 1. Macroscopic Global Repair Evaluation (GRE) according to the ICRS scores.

\begin{tabular}{|lllllll|}
\hline & Group & Average & $\begin{array}{l}\text { Standard } \\
\text { error }\end{array}$ & $\begin{array}{l}\text { Standard } \\
\text { deviation }\end{array}$ & Median & $P$ \\
\hline $\begin{array}{l}\text { Global Repair } \\
\text { Evaluation (GRE) }\end{array}$ & SMMSC free (GA) & 8.600 & 0.400 & 0.894 & 8.000 & 0.007 \\
\cline { 2 - 5 } & $\begin{array}{l}\text { SMMSC } \\
\text { encapsulated (GB) }\end{array}$ & 10.000 & 0.707 & 1.581 & 10.000 & \\
& \begin{tabular}{llllll} 
Control (GC) \\
\hline
\end{tabular} & 6.600 & 0.245 & 0.548 & 7.00 \\
\hline
\end{tabular}

Histological analysis (HE and Toluidine Blue) revealed different degrees of fibrocartilage deposition. However, while the control group presented only fibrosis and fibrocartilage with no chondrocytes or extracellular glycosaminoglycan matrix, GB and GA treatments lead to a better tissue organization, visible chondrocytes and extracellular matrix deposition (Figure 9).

Immunohistochemistry for collagen type II did not reveal statistical differences, even though GB and GA treatments lead to higher labelling scores ( 4 and 3, respectively), in contrast to the score 2 in the control group (Figure 9).

Histological scoring of $\mathrm{O}^{\prime}$ DRISCOLL revealed statistical differences between groups in structural integrity $(P=0.028)$, chondrocyte grouping $(P=0.013)$ and lateral integration of the tissue $(P=0.031)$.

Tendency towards statistical significance occurred between GB and GC in tissue morphology $(P=0.07)$. Median of chondrocyte grouping was lower in the GA (Figure 10). 


\section{Discussion}

Several strategies have been developed to avoid chondral loss and OA development. Stem cells are an important treatment option due to their immunomodulatory properties $(23,24)$. Synovial membrane MSCs have demonstrated better chondrogenic differentiation $(8,25)$, being previously proven to be compatible with alginate capsules (20).

Recommended therapeutic cell concentration fluctuates around 10 to 30 million (26). However, free MSC injection can lead to cell dispersion in 7 days $(17,27-29)$. In order to reduce cell dispersion, previous studies used activated PRP as a cell scaffold, achieving significant results (30). Other studies using MSCs in scaffolds also demonstrated good therapeutic and differentiation potential in bone defects (31). However, to the authors' knowledge, the use of MSCs encapsulated in sodium alginate to treat chondral lesions in horses has not been previously described, bringing originality to the present study.

The maintenance of physical parameters after MSCs injection reinforces the biosafety of this treatment and corroborates previous studies $(32,33)$. Transitory lameness was described by some authors after MSC injection $(32,34)$. Similar findings were reported in LPS-induced synovitis treated with MSCs $(35$, 36). In contrast, absence of lameness has also been described after MSC injection (37).

Intraarticular injection of autologous, allogeneic or xenogeneic bone marrow MSCs can alone increase TNCC in horses $(32,37,38)$. In our study, besides MSCs, the alginate and the experimental lesion contributed to the inflammation process. Although alginate itself is inert, the calcium used in the crosslinking process can exert an immunogenic effect (39). Another study using alginate capsules injected in the peritoneal cavity of mice also demonstrated a significant increase of inflammatory cells after 48,96 and 168h (40). It is important to point out that the absence of a group with alginate alone (without MSCs), in order to evaluate the isolated effect of alginate capsules, is a limiting factor of this study.

The insertion of MSCs in an alginate scaffold could have reduced their effect initially, leading to a higher inflammatory process. However, the inflammatory process decreased throughout the time, so that at the end of the study the GB revealed the lowest cell count, which leads to the inference that MSCs exerted an immunomodulatory paracrine effect despite the initial inflammation. This effect is achieved by the release of cytokines and growth factors (41-43), added to the porous structure of alginate that allows oxygen, metabolite and nutrient diffusion (44), stimulating cell proliferation and survival (45). Similar immunomodulatory effect was observed in a previous study that used MSCs in alginate hydrogel to treat neuroinflammation, reinforcing that alginate can not only act as a delivery scaffold, but also enhance MSCs therapeutic effect (46).

Although MSC injection can have contributed to the increase in neutrophil count (47), we state that the experimental lesion was the main cause of the initial inflammatory process, as all groups including the control group presented inflammation initially. While some studies show a decrease in neutrophil count 
after 7 to 9 days $(33,47)$, it remained high for 14 days in our study, corroborating other previous data (48).

Lymphocytes are cells from the adaptive immune system, attracted chemotactically by several cytokines (49). The increase in lymphocyte count at $168 \mathrm{~h}$ only in the control group may have occurred due to the ability of MSCs to reduce lymphocyte activation $(12,50)$.

Macrophages have different subtypes with different functions. They can either polarize into a proinflammatory (M1) or anti-inflammatory (M2) phenotype, depending on the environment $(51,52)$. M2 macrophages release chondrogenic factors, including IL-10, IL-1Ra and TGF $\beta(51,52)$. Although specific labelling for $\mathrm{M} 1$ and $\mathrm{M} 2$ was not performed, the positive correlation between macrophage count (MC) and IL-10 and the statistically higher IL-10 in the GB indicate a tendency towards M2 polarization, since IL-10 is required for macrophage polarization (53). Interestingly, the control group also presented a correlation between MC and IL-10, which can indicate anti-inflammatory response against the inflammation. However, further analyses of cartilage scores revealed bad cartilage aspect and histologic architecture, highlighting the important role of MSCs in interacting, organizing and orchestrating the reparative process. The final result found in the control group substantiates the inference that most of synovial macrophages did not polarize into $M 2$, given that a better outcome would be expected in a proresolutive (M2) scenario.

Increase in total protein (TP) up to $5 \mathrm{~g} / \mathrm{dL}$ has been demonstrated after allogeneic and xenogeneic MSC injections indicating inflammation (32), similar to the $24 \mathrm{~h}$ time point in GB. The positive correlation between TP and macrophage count in the GB, with concomitant decrease of both variables, reinforces the hypothesis that MSCs acted modulating the inflammatory process.

Interferon $\gamma$ increased at $24 \mathrm{~h}$ in the GB, and at 24,168 and $336 \mathrm{~h}$ in GA. Since IFN $\gamma$ is related to M1 polarization of macrophages and increase in neutrophil and monocyte activity (54), the increase of its levels reflects the initial inflammatory process, where most macrophages generally adopt a M1 polarization $(51,52)$. Even with a strong positive correlation between IFN $\gamma$ and TNF-a, a better outcome was noticed in both treated groups, which indicates that despite the pro-inflammatory commitment of these cytokines, the initial inflammatory process elicited a MSC anti-inflammatory response, corroborating previous findings (55).

The role of IL-6 in horses is not completely understood. It can be released in LPS-induced arthritis (56), acting as a pro-inflammatory cytokine through the delay in lymphocyte and neutrophil apoptosis and decrease in T-cell stimulation $(56,57)$. However, immunoregulatory properties have been also attributed to IL-6, demonstrating a dual role of this cytokine (58). Since the peak of IL-6 occurred at $96 \mathrm{~h}$ in the GB, alongside with a decrease in neutrophil and total nucleated cell count and an increase in IL-10, we infer that IL-6 exerted an immunoregulatory effect in this case. The absence of simultaneous increase in IL-6, IL-1 and TNFa corroborates this affirmation, since in a pro-inflammatory scenario IL- 6 is involved in chondral matrix degradation alongside IL-1 and TNFa (59-61). 
In contrast, IL-10 was increased in the encapsulated GB. When properly stimulated, MSCs can release IL10 and other anti-inflammatory molecules like IL-1 ra, indoleamine 2,3-dioxygenase, TGF- $\beta$ and PGE2 (10, $29,30)$. Thus, it is possible that encapsulated MSCs released IL-10 in response to the initial inflammatory process.

The presence of a well-attached, white and firm cartilage-like tissue has been previously reported after PRP injection in both experimental and natural chondral lesions in horses (62-64). When PRP was associated with MSCs, a superiority in collagen type II deposition, macroscopic and histological appearance was reported (65). Better macro and microscopic aspects observed in the GB, with higher glycosaminoglycan deposition and better O'Driscoll scores, makes a great contrast with the GA and GC, which presented prevalence of fibrous tissue.

Taken together, data of this study indicate a better outcome in cartilage condition after injecting MSCs encapsulated in alginate, but the exact mechanisms that make this combination superior remain not completely elucidated. Besides providing a scaffold for MSCs tridimensional organization, alginate encapsulation is a cell delivery mechanism capable of improving cell therapeutic effects due to the maintenance of MSCs for a longer time at the site of injection (66-69), which can facilitate cell-to-cell interaction and consequent secretion of specific cytokines (70) and cell stimulation $(29,42,71-73)$ that orientate the articular environment towards a pro-resolutive scenario. It is important to point out that the large synovial cavity allowed the injection of a high number of capsules. However, each case needs to be evaluated individually, since the number of capsules to be injected is directly related to the cell concentration.

A longer follow-up of the animals would have provided considerable data regarding collagen type II deposition, morphological and histological scores. Since each MSC source has its own particularities that may lead to different behaviors even facing the same conditions, the comparison of synovial membrane to other MSC sources would also contribute to the better understanding of the events associated with chondral healing in horses.

\section{Conclusion}

Alginate capsules with MSCs elicited a more marked initial inflammatory process. However, the inflammation was modulated through time and encapsulated MSCs produced better outcomes in terms of chondral aspect and composition. Some grade of inflammation is necessary and even desirable, which can be beneficial to the MSCs response, releasing anti-inflammatory cytokines that guide the reparative process towards resolution. Besides the safety in the application, positive results observed after administration of encapsulated MSCs to treat chondral defects substantiates further studies that aim to clarify the immunomodulatory effect of encapsulated MSC under different conditions.

\section{Abbreviations}


SMMSC: Synovial membrane mesenchymal stem cells; PBS: Phosphate Buffered Saline; IL- interleukin; INF: interferon; TNF: tumor necrosis factor; TGF: Transforming growth factor; IGF: insulin growth factor; PGE: prostaglandin E; OA: osteoarthritis; MSC: Mesenchymal stem cell; GA: SMMSC alone; GB: encapsulated ${ }_{S M} M S C$; $\mathrm{GC}$ control; $\mathrm{CaCl}$ : calcium chloride; $\mathrm{NaCl}$ : Sodium chloride; ICRS: International Cartilage Repair Society; IHC: Immunohistochemistry; DAB: 3,3'-diaminobenzidine tetrahydrochloride; TNC: total nucleated cells; TP: total protein; SAA: serum amyloid A; SP: substance P; NC: nucleated cells; MC: macrophages cells; LC: lymphocytes cells; GRE: Global Repair Evaluation; HE: hematoxylin eosin; COL II: collagen type II; PRP: plasma rich platelets; LPS: lipopolysaccharide.

\section{Declarations}

\section{Acknowledgements}

We thank the São Paulo Research Foundation (FAPESP grant number 2017/12815-0 and 2017/144604), the Coordination for the Improvement of Higher Education Personnel (CAPES) and the National Council for Scientific and Technological Development (CNPq), for funding this study.

\section{Authors' contributions}

VH conceived the study and participated in its design, execution and coordination, in addition to writing the manuscript. JP, FC, MC and EV conceived the study and participated in its design, execution, data collection and manuscript review. GS conceived the study and participated in its design, execution, data collection and manuscript review. LV and TR participated in the design of the study and performed the statistical analysis. CE participated in the design of the study and performed histological and immunohistochemical analysis. AL conceived the study, coordinated the research and carried out the writing and revision of the manuscript. All authors read and approved the final manuscript.

\section{Funding}

São Paulo Research Foundation (FAPESP grant number 2017/12815-0 and 2017/14460-4), financial assistance for carrying out the entire research project. The Coordination for the Improvement of Higher Education Personnel (CAPES) and the National Council for Scientific and Technological Development (CNPq), contributed to the assistance of authors with scholarships.

\section{Availability of data and materials}

The authors do not share the data due to the pioneering work in the equine species.

\section{Declarations}

\section{Ethics Committee approval}


All experimental procedures were carried out in accordance with the approved guidelines and regulations of the Ethics Committee of São Paulo State University (protocol n. 032/2020).

\section{Consent for publication}

Not applicable.

\section{Competing interests}

The authors declare that they have no competing interests.

\section{Author details}

${ }^{[1]}$ University of Veterinary Medicine and Animal Science UNESP, District of Rubião Júnior, s/n, Botucatu, São Paulo, Brazil. ${ }^{2}$ University State Londrina (UEL), Highway Celso Garcia Cid KM 380, Londrina, Paraná, Brazil. *Correspondence: ana.liz@unesp.br

\section{References}

1. Sutton S, Clutterbuck A, Harris P, Gent T, Freeman S, Foster N, et al. The contribution of the synovium, synovial derived inflammatory cytokines and neuropeptides to the pathogenesis of osteoarthritis. Vet J. 2009;179(1):10-24. http://dx.doi.org/10.1016/j.tvjl.2007.08.013

2. Alcaraz MJ, Megías J, García-Arnandis I, Clérigues V, Guillén MI. New molecular targets for the treatment of osteoarthritis. Biochemical Pharmacology. 2010. https://doi.org/10.1016/j.bcp.2010.02.017.

3. Mcllwraith CW, Frisbie DD, Kawcak CE. The horse as a model of naturally occurring osteoarthritis. Bone Joint Res. 2012;1(11):297-309. https://doi.org/10.1302/2046-3758.111.2000132.

4. Madeira C, Santhagunam A, Salgueiro JB, Cabral JMS. Advanced cell therapies for articular cartilage regeneration. Trends Biotechnol. 2015;33(1):35-42. https://doi.org/10.1016/j.tibtech.2014.11.003.

5. Yamada ALM, Carvalho A de M, Moroz A, Deffune E, Watanabe MJ, Hussni CA, et al. Mesenchymal stem cell enhances chondral defects healing in horses. Stem Cell Discov. 2013;03(04):218-25. http://dx.doi.org/10.4236/scd.2013.34027.

6. Yoshimura H, Muneta T, Nimura A, Yokoyama A, Koga H, Sekiya I. Comparison of rat mesenchymal stem cells derived from bone marrow, synovium, periosteum, adipose tissue, and muscle. Cell Tissue Res. 2007. https://doi.org/10.1007/s00441-006-0308-z.

7. De Bari C, Dell'Accio F, Tylzanowski P, Luyten FP. Multipotent mesenchymal stem cells from adult human synovial membrane. Arthritis Rheum. 2001. https://doi.org/10.1002/15290131(200108)44:8<1928::AID-ART331>3.0.C0;2-P.

8. Sakaguchi Y, Sekiya I, Yagishita K, Muneta T. Comparison of human stem cells derived from various mesenchymal tissues: Superiority of synovium as a cell source. Arthritis Rheum. 2005. https://doi.org/10.1002/art.21212. 
9. Lee JC, Min HJ, Park HJ, Lee S, Seong SC, Lee MC. Synovial membrane-derived mesenchymal stem cells supported by platelet-rich plasma can repair osteochondral defects in a rabbit model. Arthrosc J Arthrosc Relat Surg. 2013;29(6):1034-46. http://dx.doi.org/10.1016/j.arthro.2013.02.026.

10. Shi Y, Su J, Roberts Al, Shou P, Rabson AB, Ren G. How mesenchymal stem cells interact with tissue immune responses. Trends Immunol [Internet]. 2012;33(3):136-43. http://dx.doi.org/10.1016/j.it.2011.11.004

11. van Lent PLEM, van den Berg WB. Mesenchymal stem cell therapy in osteoarthritis: Advanced tissue repair or intervention with smouldering synovial activation? Arthritis Res Ther. 2013;15(2):1-2. https://doi.org/10.1186/ar4190.

12. Nöth $U$, Steinert AF, Tuan RS. Technology Insight: Adult mesenchymal stem cells for osteoarthritis therapy. Nature Clinical Practice Rheumatology. 2008. https://doi.org/10.1038/ncprheum0816.

13. Drengk A, Zapf A, Stürmer EK, Stürmer KM, Frosch KH. Influence of platelet-rich plasma on chondrogenic differentiation and proliferation of chondrocytes and mesenchymal stem cells. Cells Tissues Organs. 2009. https://doi.org/10.1159/000151290.

14. Coleman CM, Curtin C, Barry FP, O’Flatharta C, Murphy JM. Mesenchymal stem cells and osteoarthritis: Remedy or accomplice? Hum Gene Ther. 2010;21(10):1239-50. https://doi.org/10.1089/hum.2010.138.

15. Frisbie DD, Smith RKW. Clinical update on the use of mesenchymal stem cells in equine orthopaedics. Equine Veterinary Journal. 2010. https://doi.org/10.2746/042516409X477263.

16. Frisbie DD, Stewart MC. Cell-based Therapies for Equine Joint Disease. Veterinary Clinics of North America - Equine Practice. 2011. https://doi.org/10.1016/j.cveq.2011.06.005

17. Santos VH, Pfeifer JPH, Souza JB, Stievani FDC, Hussni CA, Golim MDA, Deffune E, Alvez ALG. Evaluation of alginate hydrogel encapsulated mesenchymal stem cell migration in horses. Res Vet Sci. 2019;124:38-45. https://doi.org/10.1016/j.rvsc.2019.02.005

18. Ayral X. Injections in the treatment of osteoarthritis. Best Pract Res Clin Rheumatol. 2001. https://doi.org/10.1053/berh.2001.0177.

19. Freshney RI. Culture of Animal Cells: A Manual of Basic Technique and Specialized Applications: Sixth Edition. Culture of Animal Cells: A Manual of Basic Technique and Specialized Applications: Sixth Edition. 2011.

20. Santos VH, Pfeifer JPH, de Souza JB, Milani BHG, de Oliveira RA, Assis MG, et al. Culture of mesenchymal stem cells derived from equine synovial membrane in alginate hydrogel microcapsules. BMC Vet Res. 2018;14(1):1-10. https://doi.org/10.1186/s12917-018-1425-0

21. Mcllwraith CW, Nixon AJ, Wright IM, Boening KJ. Diagnostic and Surgical Arthroscopy in the Horse. Diagnostic and Surgical Arthroscopy in the Horse. 2005.

22. dos Anjos DS, Vital AF, Lainetti P de F, Leis-Filho AF, Dalmolin F, Elias F, et al. Deregulation of VEGFR2 and PDGFR expression and microvascular density in a triple-negative model of canine malignant mammary tumors with lymph node or lung metastasis. Vet Sci. 2019. https://doi.org/10.3390/vetsci6010003. 
23. Tsai S-Y. Intra-articular transplantation of porcine adipose-derived stem cells for the treatment of canine osteoarthritis: A pilot study. World J Transplant. 2014. http://doi.org/ 10.5500/wjt.v4.i3.196.

24. Gutierrez-Fernandez M, Rodríguez-Frutos B, Ramos-Cejudo J, Otero-Ortega L, Fuentes B, VallejoCremades TT, et al. Comparison between xenogeneic and allogeneic adipose mesenchymal stem cells in the treatment of acute cerebral infarct: Proof of concept in rats. J Transl Med. 2015. https://doi.org/10.1186/s12967-015-0406-3.

25. To K, Zhang B, Romain K, Mak C, Khan W. Synovium-Derived Mesenchymal Stem Cell Transplantation in Cartilage Regeneration: A PRISMA Review of in vivo Studies. Frontiers in Bioengineering and Biotechnology. 2019. https://doi.org/10.3389/fbioe.2019.00314.

26. Wike MM, Nydam DV, Nixon AJ. Enhanced early chondrogenesis in articular defects following arthroscopic mesenchymal stem cell implantation in an equine model. J Orthop Res. 2007;25(7):91325. https://doi.org/10.1002/jor.20382

27. Horie M, Choi H, Lee RH, Reger RL, Ylostalo J, Muneta T, et al. Intra-articular injection of human mesenchymal stem cells (MSCs) promote rat meniscal regeneration by being activated to express Indian hedgehog that enhances expression of type II collagen. Osteoarthr Cartil. 2012. https://doi.org/10.1016/j.joca.2012.06.002.

28. Ozeki N, Muneta T, Koga H, Nakagawa Y, Mizuno M, Tsuji K, et al. Not single but periodic injections of synovial mesenchymal stem cells maintain viable cells in knees and inhibit osteoarthritis progression in rats. Osteoarthr Cartil. 2016. https://doi.org/10.1016/j.joca.2015.12.018.

29. Ter Huurne M, Schelbergen R, Blattes R, Blom A, De Munter W, Grevers LC, et al. Antiinflammatory and chondroprotective effects of intraarticular injection of adipose-derived stem cells in experimental osteoarthritis. Arthritis Rheum. 2012. https://doi.org/10.1002/art.34626.

30. Yamada ALM, Alvarenga ML, Brandão JS, Watanabe MJ, Rodrigues CA, Hussni CA, et al. Arcabouço de PRP-gel associado a células tronco mesenquimais: Uso em lesões condrais em modelo experimental equino. Pesqui Vet Bras. 2016;36(6):461-7. https://doi.org/10.1590/S0100736X2016000600001

31. He X, Liu Y, Yuan X, Lu L. Enhanced healing of rat calvarial defects with MSCs loaded on BMP-2 releasing chitosan/alginate/hydroxyapatite scaffolds. PLoS One. 2014. https://doi.org/10.1371/journal.pone.0104061.

32. Pigott JH, Ishihara A, Wellman ML, Russell DS, Bertone AL. Inflammatory effects of autologous, genetically modified autologous, allogeneic, and xenogeneic mesenchymal stem cells after intraarticular injection in horses. Vet Comp Orthop Traumatol. 2013; 26(6):453-60. http://doi.org/10.3415/VCOT-13-01-0008

33. Boone L. Intra-articular administration of allogeneic equine bone derived mesenchymal stem cells. Athens, Georgia: University of Georgia.; 2013.

34. Stashak TS. Claudicação em equinos. 5a.ed. Roca, editor. São Paulo: Roca; 2006. 1093p.

35. Williams LB, Koenig JB, Black B, Gibson TWG, Sharif S, Koch TG. Equine allogeneic umbilical cord blood derived mesenchymal stromal cells reduce synovial fluid nucleated cell count and induce mild 
self-limiting inflammation when evaluated in an LPS induced synovitis model. Equine Vet $\mathrm{J}$. 2015;48(5):619-25. https://doi.org/10.1111/evj.12477.

36. Rosa G, Krieck AMT, Padula E, Pfeifer JPH, de Souza JB, Rossi M, et al. Allogeneic synovial membrane-derived mesenchymal stem cells do not significantly affect initial inflammatory parameters in a LPS-induced acute synovitis model. Res Vet Sci. 2020. https://doi.org/10.1016/j.rvsc.2020.08.001.

37. Ardanaz N, Vázquez FJ, Romero A, Remacha AR, Barrachina L, Sanz A, et al. Inflammatory response to the administration of mesenchymal stem cells in an equine experimental model: Effect of autologous, and single and repeat doses of pooled allogeneic cells in healthy joints. BMC Vet Res [Internet]. 2016;12(1):1-9. http://dx.doi.org/10.1186/s12917-016-0692-x.

38. Colbath AC, Dow SW, Hopkins LS, Phillips JN, Mcllwraith CW, Goodrich LR. Single and repeated intraarticular injections in the tarsocrural joint with allogeneic and autologous equine bone marrowderived mesenchymal stem cells are safe, but did not reduce acute inflammation in an experimental interleukin-1ß model of synovitis. Equine Vet J. 2020. https://doi.org/10.1111/evj.13222.

39. Chan G, Mooney DJ. Ca2+ released from calcium alginate gels can promote inflammatory responses in vitro and in vivo. Acta Biomater. 2013. https://doi.org/10.1016/j.actbio.2013.08.002.

40. Robitaille R, Dusseault J, Henley N, Desbiens K, Labrecque N, Hallé JP. Inflammatory response to peritoneal implantation of alginate-poly-L-lysine microcapsules. Biomaterials. 2005. https://doi.org/10.1016/j.biomaterials.2004.10.028.

41. da Silva Meirelles L, Fontes AM, Covas DT, Caplan Al. Mechanisms involved in the therapeutic properties of mesenchymal stem cells. Cytokine and Growth Factor Reviews. 2009. https://doi.org/10.1016/j.cytogfr.2009.10.002.

42. Desando G, Cavallo C, Sartoni F, Martini L, Parrilli A, Veronesi F, et al. Intra-articular delivery of adipose derived stromal cells attenuates osteoarthritis progression in an experimental rabbit model. Arthritis Res Ther. 2013. https://doi.org/10.1186/ar4156.

43. Kim YS, Choi YJ, Koh YG. Mesenchymal Stem Cell Implantation in Knee Osteoarthritis: An Assessment of the Factors Influencing Clinical Outcomes. Am J Sports Med. 2015. https://doi.org/10.1177/0363546515588317.

44. Sun J, Tan H. Alginate-based biomaterials for regenerative medicine applications. Materials (Basel). 2013;6(4):1285-309. https://doi.org/10.3390/ma6041285.

45. Spees JL, Lee RH, Gregory CA. Mechanisms of mesenchymal stem/stromal cell function. Stem Cell Res Ther. 2016;7(1):1-13. http://dx.doi.org/10.1186/s13287-016-0363-7.

46. Stucky EC, Schloss RS, Yarmush ML, Shreiber DI. Alginate micro-encapsulation of mesenchymal stromal cells enhances modulation of the neuro-inflammatory response. Cytotherapy. 2015. https://doi.org/10.1016/j.jcyt.2015.05.002.

47. Joswig AJ, Mitchell A, Cummings KJ, Levine GJ, Gregory CA, Smith R, et al. Repeated intra-articular injection of allogeneic mesenchymal stem cells causes an adverse response compared to 
autologous cells in the equine model. Stem Cell Res Ther. 2017. https://doi.org/10.1186/s13287017-0503-8.

48. Bertoni L, Branly T, Jacquet S, Desancé M, Desquilbet L, Rivory P, et al. Intra-articular injection of 2 different dosages of autologous and allogeneic bone marrow- And umbilical cord-derived mesenchymal stem cells triggers a variable inflammatory response of the fetlock joint on 12 sound experimental horses. Stem Cells Int. 2019. https://doi.org/10.1155/2019/9431894.

49. Cruvinel W de M, Mesquita Júnior D, Araújo JAP, Catelan TTT, Souza AWS de, Silva NP da, et al. Sistema imunitário: Parte I. Fundamentos da imunidade inata com ênfase nos mecanismos moleculares e celulares da resposta inflamatória. Rev Bras Reumatol. 2010. https://doi.org/10.1590/S0482-50042010000400008.

50. Vinatier C, Mrugala D, Jorgensen C, Guicheux J, Noël D. Cartilage engineering: a crucial combination of cells, biomaterials and biofactors. Trends Biotechnol. 2009;27(5):307-14. https://doi.org/10.1016/j.tibtech.2009.02.005.

51. Fernandes TL, Gomoll AH, Lattermann C, Hernandez AJ, Bueno DF, Amano MT. Macrophage: A Potential Target on Cartilage Regeneration. Front Immunol. 2020;11(February):1-9. https://doi.org/10.3389/fimmu.2020.00111.

52. Davis MJ, Tsang TM, Qiu Y, Dayrit JK, Freij JB, Huffnagle GB, et al. Macrophage M1/M2 polarization dynamically adapts to changes in cytokine microenvironments in Cryptococcus neoformans infection. MBio. 2013;4(3):1-10. http://doi.org/ 10.1128/mBio.00264-13.

53. Lopes RL, Borges TJ, Zanin RF, Bonorino C. IL-10 is required for polarization of macrophages to M2like phenotype by mycobacterial DnaK (heat shock protein 70). Cytokine. 2016. https://doi.org/10.1016/j.cyto.2016.06.018.

54. Akdis M, Burgler S, Crameri R, Eiwegger T, Fujita H, Gomez E, et al. Interleukins, from 1 to 37, and interferon- $\gamma:$ Receptors, functions, and roles in diseases. J Allergy Clin Immunol. 2011. https://doi.org/10.1016/j.jaci.2010.11.050.

55. Cuerquis J, Romieu-Mourez R, François M, Routy JP, Young YK, Zhao J, et al. Human mesenchymal stromal cells transiently increase cytokine production by activated T cells before suppressing T-cell proliferation: Effect of interferon-y and tumor necrosis factor-a stimulation. Cytotherapy. 2014. https://doi.org/10.1016/j.jcyt.2013.11.008.

56. Raffaghello L, Bianchi G, Bertolotto M, Montecucco F, Busca A, Dallegri F, et al. Human Mesenchymal Stem Cells Inhibit Neutrophil Apoptosis: A Model for Neutrophil Preservation in the Bone Marrow Niche. Stem Cells. 2008. https://doi.org/10.1634/stemcells.2007-0416.

57. Iwamoto M, Kurachi M, Nakashima T, Kim D, Yamaguchi K, Oda T, et al. Structure-activity relationship of alginate oligosaccharides in the induction of cytokine production from RAW264.7 cells. FEBS Lett. 2005. https://doi.org/10.1016/j.febslet.2005.07.007.

58. Smith JK. IL-6 and the dysregulation of immune, bone, muscle, and metabolic homeostasis during spaceflight. npj Microgravity. 2018;4(1):1-8. http://dx.doi.org/10.1038/s41526-018-0057-9 
59. Venn G, Nietfeld JJ, Duits AJ, Brennan FM, Arner E, Covington M, et al. Elevated synovial fluid levels of interleukin- 6 and tumor necrosis factor associated with early experimental canine osteoarthritis. Arthritis Rheum. 1993. https://doi.org/10.1002/art.1780360613.

60. Wittenberg RH, Willburger RE, Kleemeyer KS, Peskar BA. In vitro release of prostaglandins and leukotrienes from synovial tissue, cartilage, and bone in degenerative joint diseases. Arthritis Rheum. 1993. https://doi.org/10.1002/art.1780361017.

61. Alwan WH, Carter SD, Dixon JB, Bennett D, May SA, Edwards GB. Interleukin-1-like activity in synovial fluids and sera of horses with arthritis. Res Vet Sci. 1991. https://doi.org/10.1016/00345288(91)90034-L.

62. Yamada ALM, Carvalho AM, Oliveira PGG, Felisbino SL, Queiroz DL, Watanabe MJ, et al. Plasma rico em plaquetas no tratamento de lesões condrais articulares induzidas experimentalmente em equinos: Avaliação clínica, macroscópica, histológica e histoquímica. Arq Bras Med Vet e Zootec. 2012. http://doi.org/ 10.1590/S0102-09352012000200010.

63. Rodkey WG, Mcllwraith CW, Frisbie DD, Steadman JR. Bone marrow-derived culture-expanded mesenchymal stem cells in conjunction with microfracture to treat chondral lesions in an equine model. Annual Scientific Meeting of the International Society For Hip Arthroscopy. 2012 https://doi.org/10.1016/j.arthro.2012.04.016.

64. Raheja LF, Galuppo LD, Bowers-Lepore J, Dowd JP, Tablin F, Yellowley CE. Treatment of Bilateral Medial Femoral Condyle Articular Cartilage Fissures in a Horse Using Bone Marrow-Derived Multipotent Mesenchymal Stromal Cells. J Equine Vet Sci. 2011. https://doi.org/10.1016/j.jevs.2010.12.009.

65. Mcllwraith CW, Frisbie DD, Rodkey WG, Kisiday JD, Werpy NM, Kawcak CE, et al. Evaluation of intraarticular mesenchymal stem cells to augment healing of microfractured chondral defects. Arthrosc J Arthrosc Relat Surg. 2011. https://doi.org/10.1016/j.arthro.2011.06.002

66. Barminko J, Kim JH, Otsuka S, Gray A, Schloss R, Grumet M, et al. Encapsulated mesenchymal stromal cells for in vivo transplantation. Biotechnol Bioeng. 2011. https://doi.org/10.1002/bit.23233.

67. Le Blanc K, Ringdén O. Immunomodulation by mesenchymal stem cells and clinical experience. Journal of Internal Medicine. 2007. https://doi.org/10.1111/j.1365-2796.2007.01844.x.

68. Goren A, Dahan N, Goren E, Baruch L, Machluf M. Encapsulated human mesenchymal stem cells: a unique hypoimmunogenic platform for long-term cellular therapy. FASEB J. 2010. https://doi.org/10.1096/fj.09-131888.

69. Garate A, Murua A, Orive G, Hernández RM, Pedraz JL. Stem cells in alginate bioscaffolds. Therapeutic Delivery. 2012. https://doi.org/10.4155/tde.12.53

70. Satué M, Schüler C, Ginner N, Erben RG. Intra-articularly injected mesenchymal stem cells promote cartilage regeneration, but do not permanently engraft in distant organs. Sci Rep. 2019;9(1):1-10. https://doi.org/10.1038/s41598-019-46554-5.

71. Zhang QZ, Su WR, Shi SH, Wilder-Smith P, Xiang AP, Wong A, et al. Human gingiva-derived mesenchymal stem cells elicit polarization of M2 macrophages and enhance cutaneous wound 
healing. Stem Cells. 2010. https://doi.org/10.1002/stem.503.

72. Kim J, Hematti P. Mesenchymal stem cell-educated macrophages: A novel type of alternatively activated macrophages. Exp Hematol. 2009. https://doi.org/10.1016/j.exphem.2009.09.004.

73. Maggini J, Mirkin G, Bognanni I, Holmberg J, Piazzón IM, Nepomnaschy I, et al. Mouse bone marrowderived mesenchymal stromal cells turn activated macrophages into a regulatory-like profile. PLoS One. 2010. https://doi.org/10.1371/journal.pone.0009252.

\section{Figures}
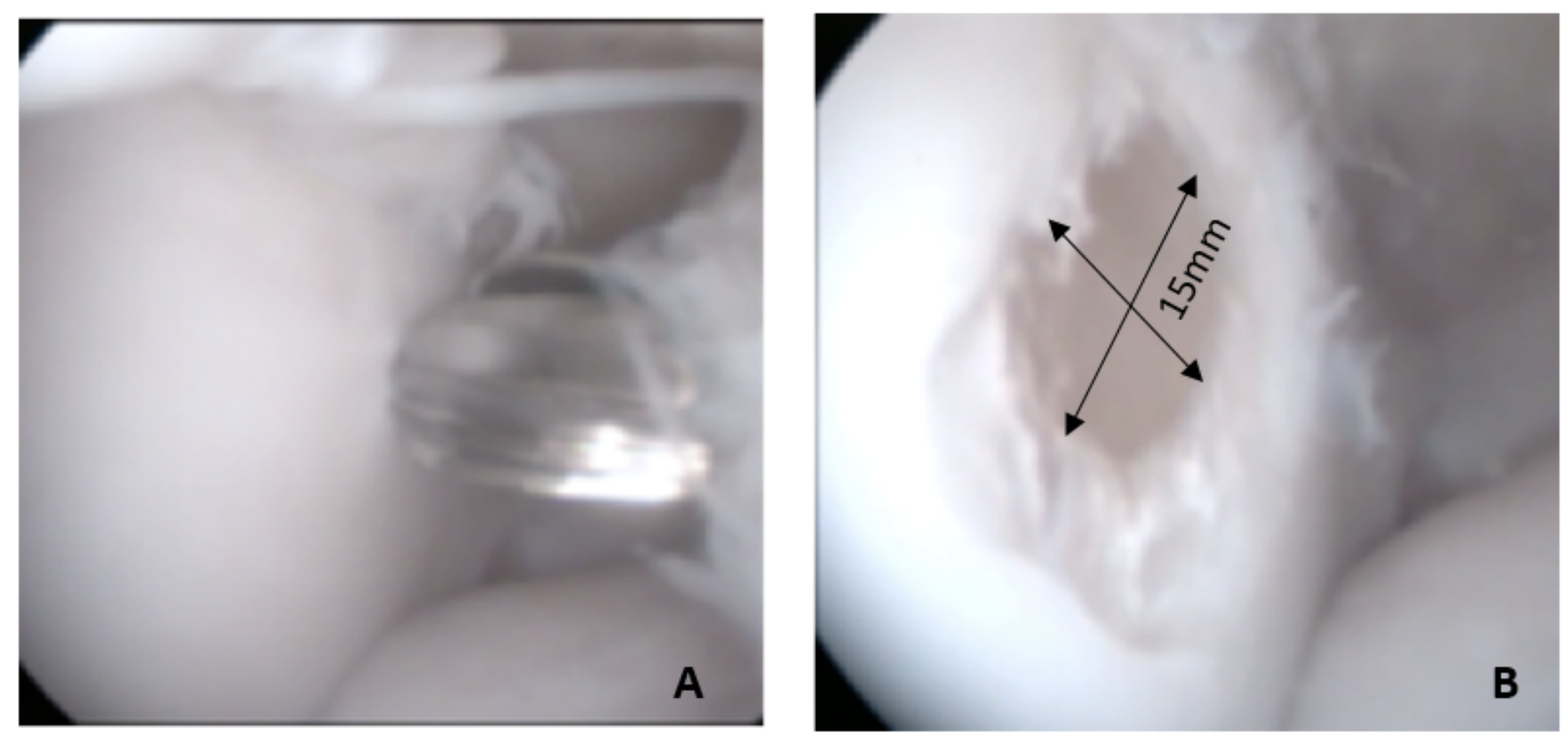

\section{Figure 1}

Tibiotarsal arthroscopy (talus medial trochlea) to induce the chondral lesion. (A) Chondral lesion at time point $0 \mathrm{~h}$ made using the shaver, removing hyaline cartilage. (B) Chondral defect of $15 \mathrm{~mm}$ diameter. 

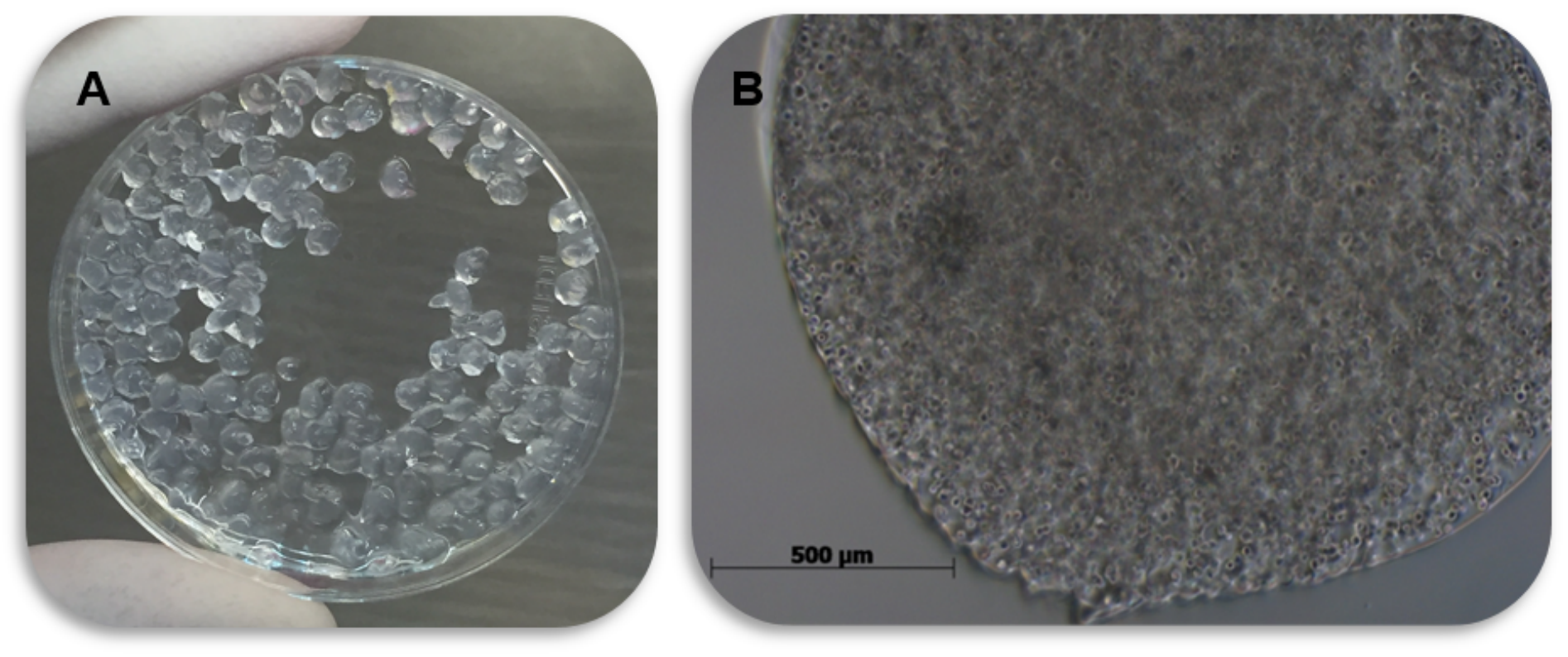

\section{Figure 2}

Equine synovial membrane-derived mesenchymal stem cells encapsulated in $1.5 \%$ sodium alginate. (A) Capsules after gelification; (B) Bright field microscopy (20x objective lens) showing cell density, viewed as little spherical structures. 

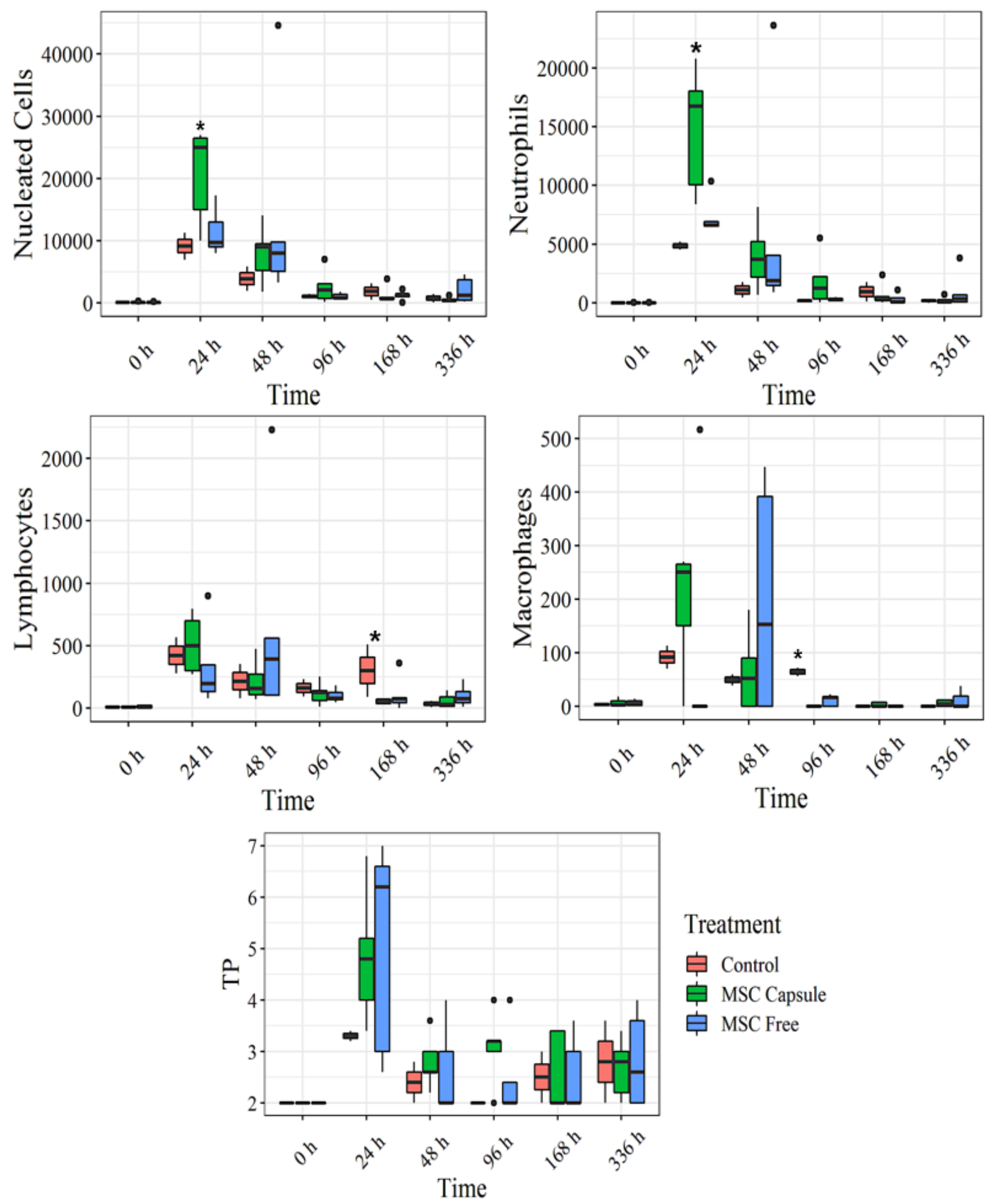

\section{Figure 3}

Total nucleated cell, neutrophil, lymphocyte and macrophage counts (cells $/ \mu \mathrm{L})$, and total protein $(\mathrm{g} / \mathrm{dL})$ of synovial fluid of the three groups. * indicates $\mathrm{P}<0.05$. 

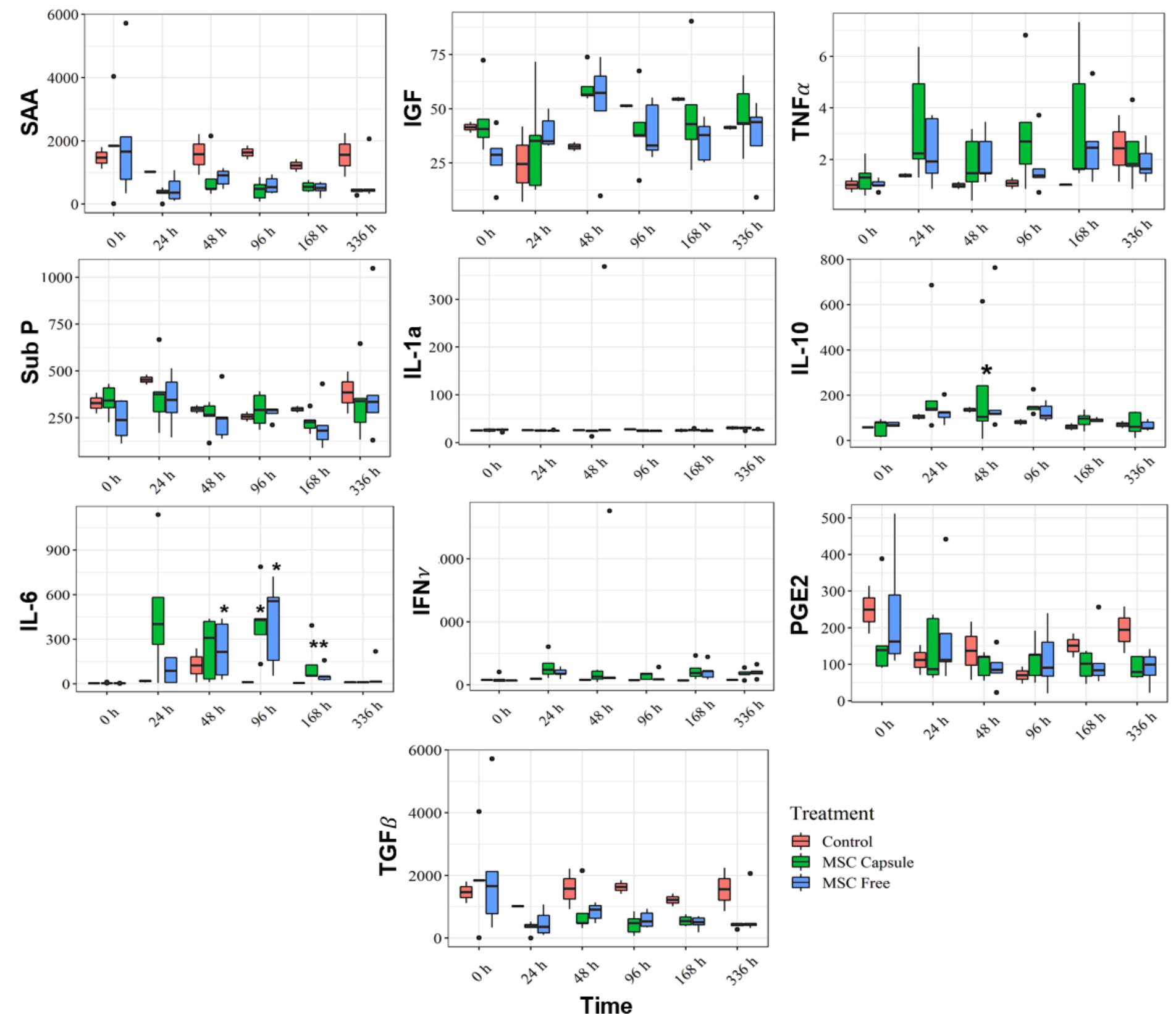

Treatment

官 Control

官 MSC Capsule

追 MSC Free

Figure 4

Median of interleukins $(/ \mu \mathrm{L})$ Serum amyloid A (SAA), IGF, TNF $\alpha$, P substance, IL-1 $\alpha$, IL-10, IL-6, IFN $\gamma$, PGE2 and TGF $\beta$ in synovial fluid of the three groups. * indicates $P>0.05$ within the group; ** indicates $P>0.05$ between groups. 


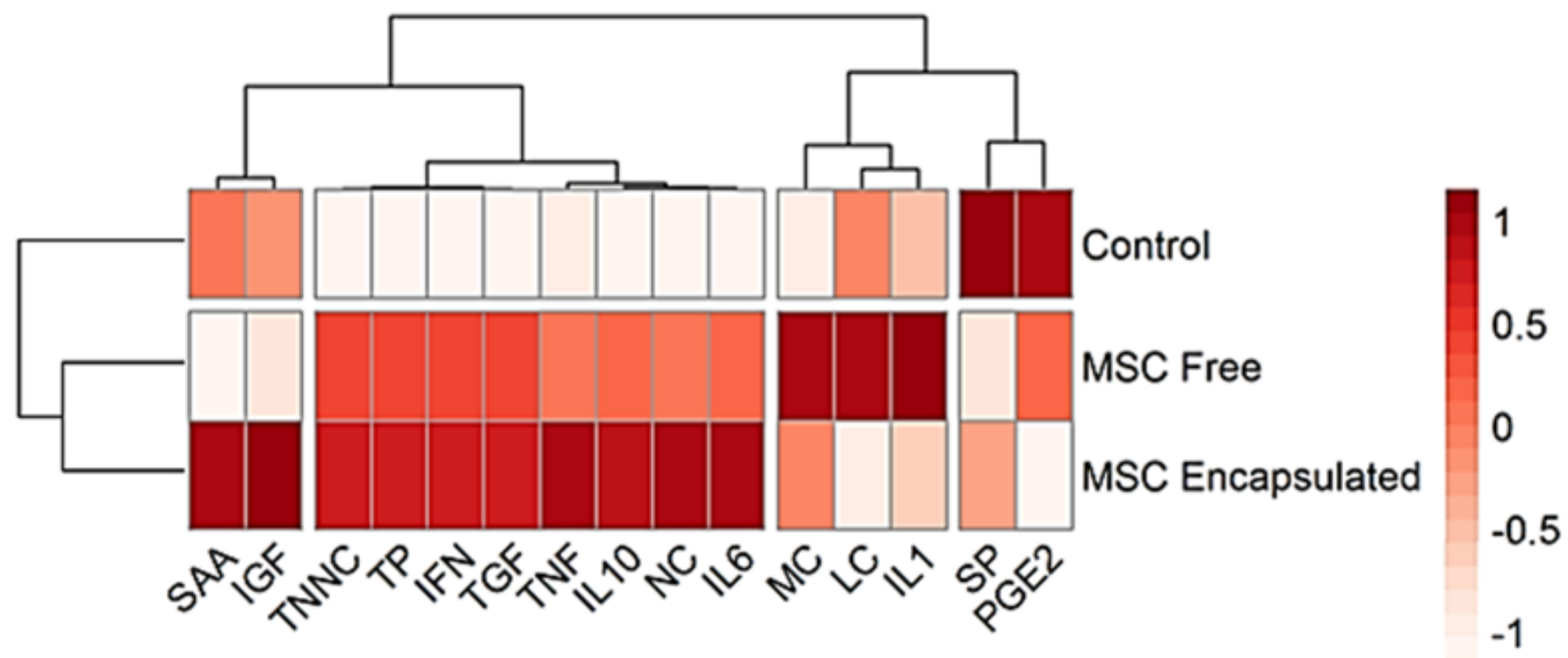

Figure 5

Heatmap of the correlation between synovial fluid SAA, IGF, TNCC, TP, IFN - $\gamma$, TNF $\alpha$, TGF $\beta$, IL-10, neutrophil count (NC), IL-6, macrophage count (MC), lymphocyte count (LC), IL-1 $\alpha$, SP, PGE2 and treatments: free MSCs (GA), Encapsulated MSCs (GB) and control group (GC). 
smMSC encapsulated

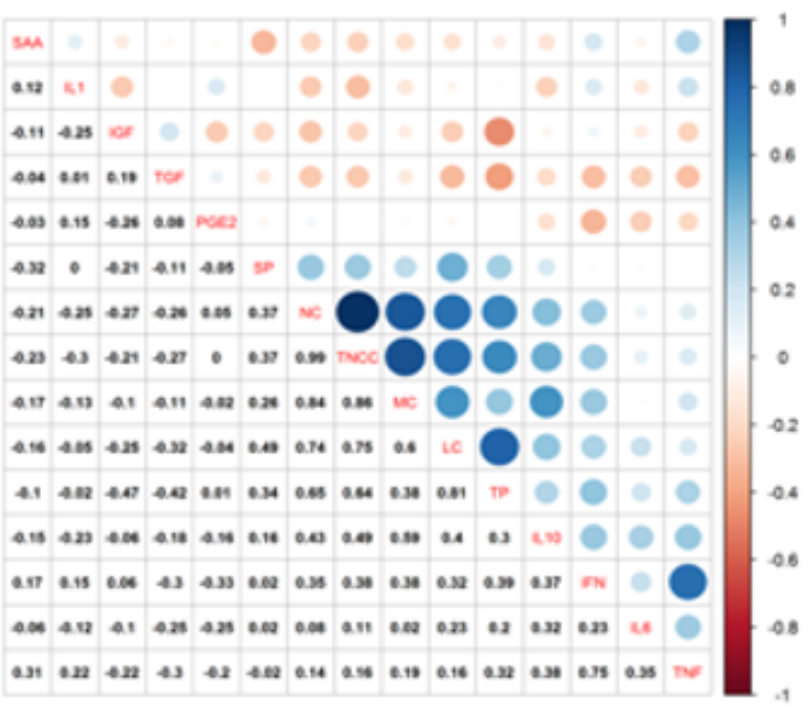

suMSC free

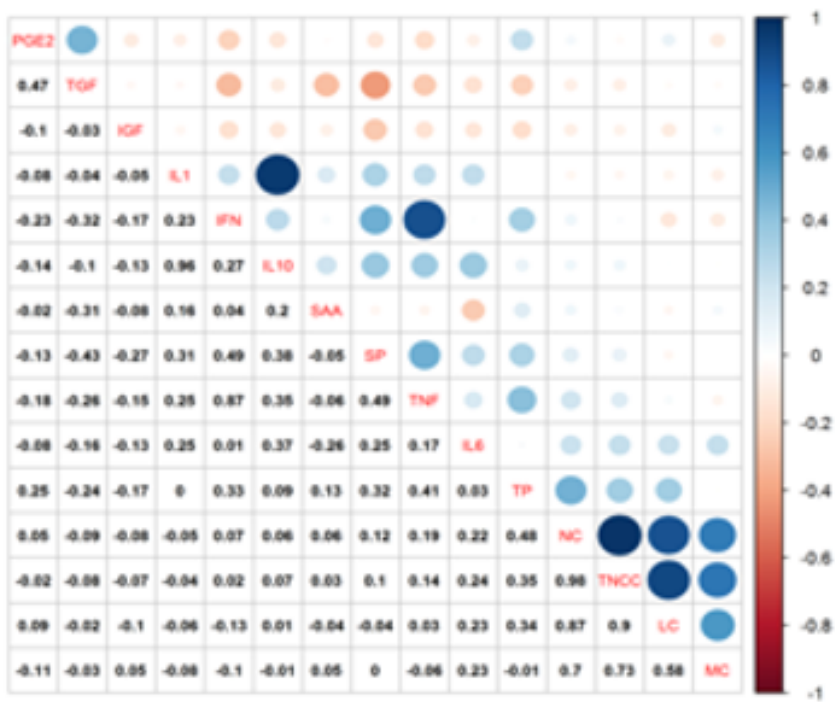

Control

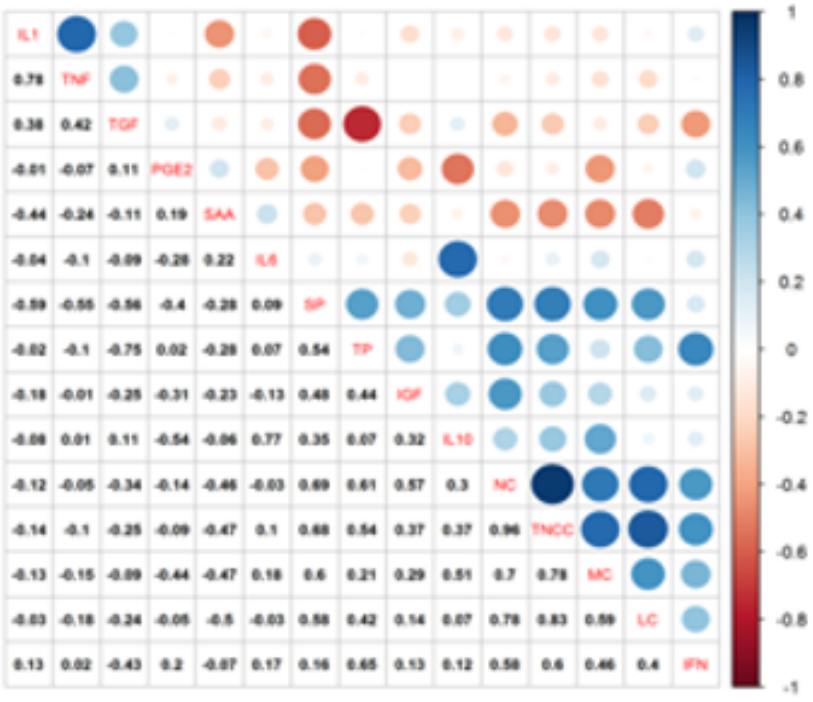

Figure 6

Pearson's correlation coefficient test between synovial fluid SAA, IGF, TNCC, TP, IFN - $\gamma$, TNF $\alpha$, TGF $\beta$, IL10, NC, IL-6, MC, LC, IL-1 $\alpha$, SP, PGE2 and treatments: free MSCs (GA), Encapsulated MSCs (GB) and control group (GC). Scores for macroscopic cartilage evaluation (figure 7). 
10

8

6

4

2

0

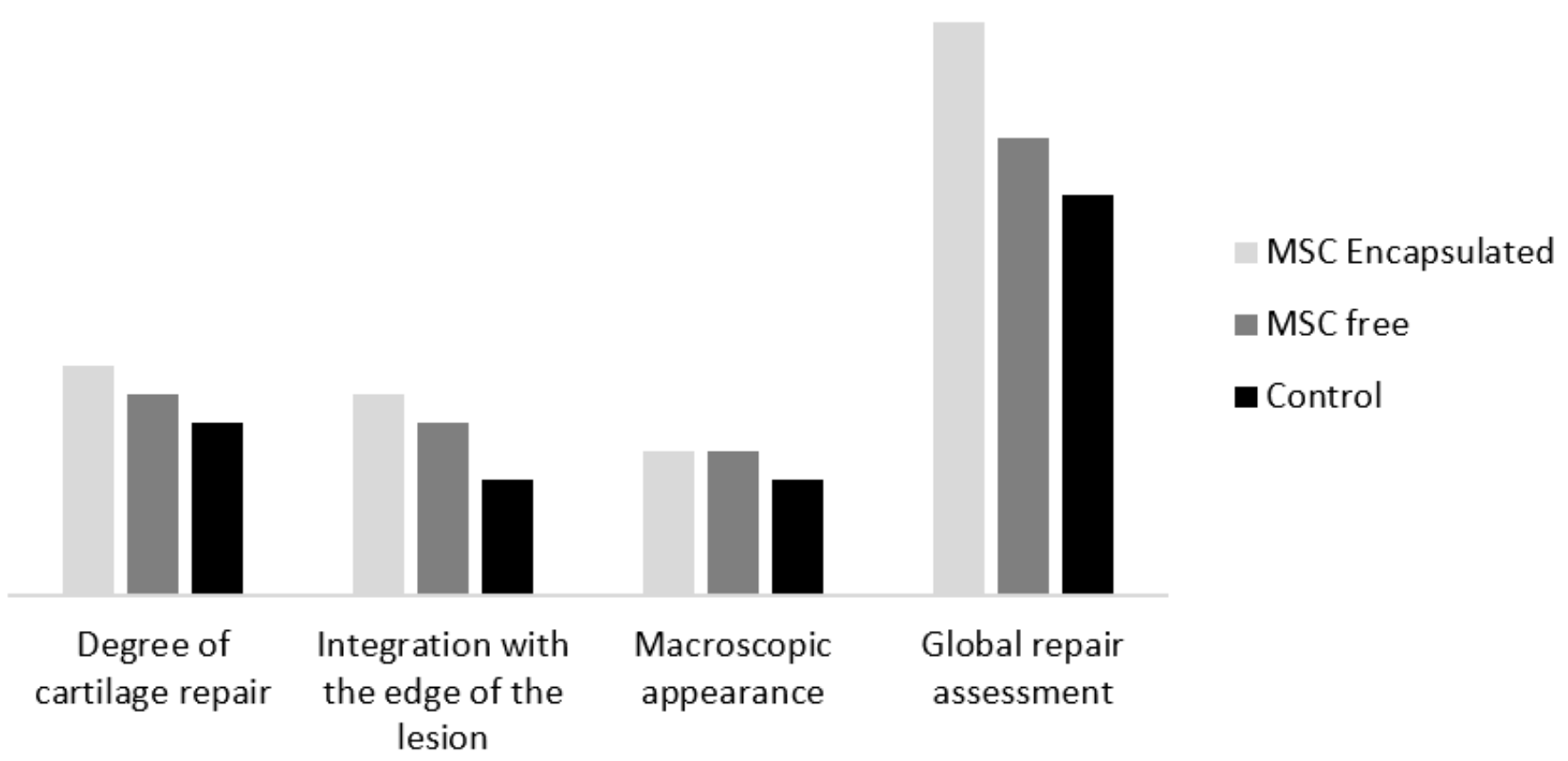

Figure 7

Mean of macroscopic evaluation according to the ICRS scores, 150 days after the induction of lesion and treatments. 


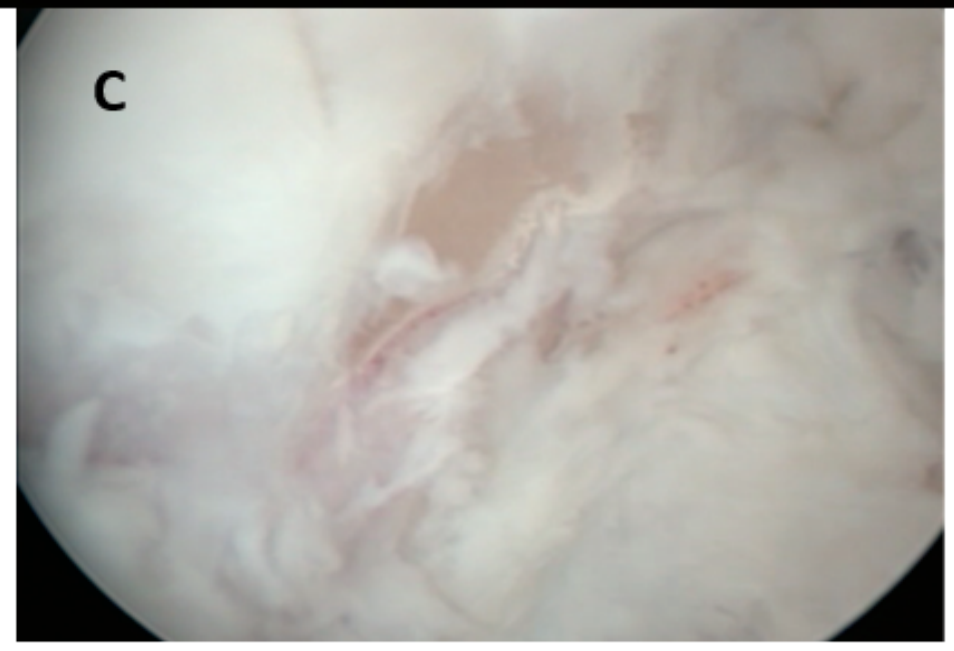

\section{Figure 8}

Macroscopic evaluation after 150 days. (A) Encapsulated MSC group (GB) showing total filling of the lesion by the neo-formed tissue. (B) Free MSCs group (GA) revealing chondral erosions and peripheral detachments. (C) Control group (GC) exhibiting fibrosis, erosion and friable-poorly attached tissue. 
AT
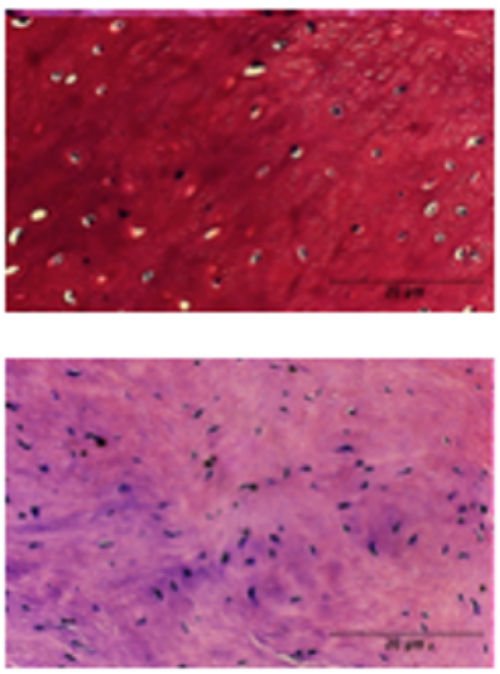

suMSC free

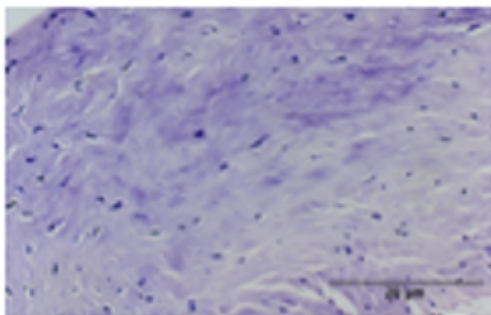

HE
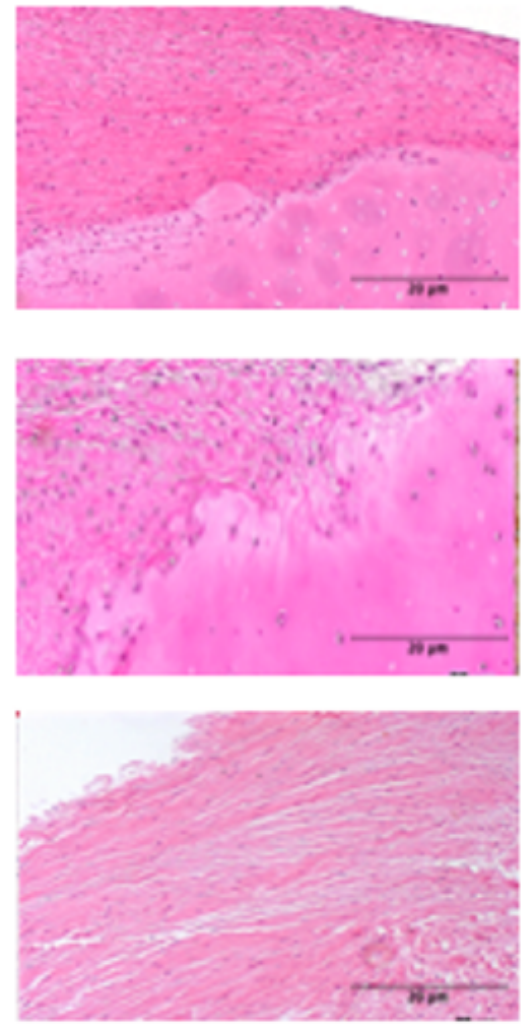

COL II
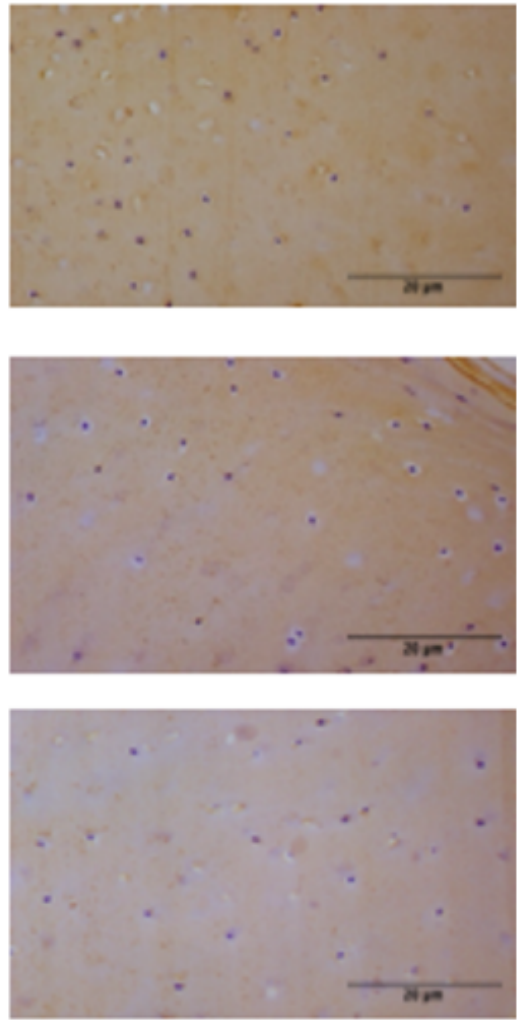

\section{Figure 9}

Bright field microscopy at 150 days. Tissue was stained in HE, Toluidine Blue and immunohistochemistry for collagen type II (COL II). Encapsulated and free MSCs revealed better structural organization, presence of chondrocytes and extracellular matrix.
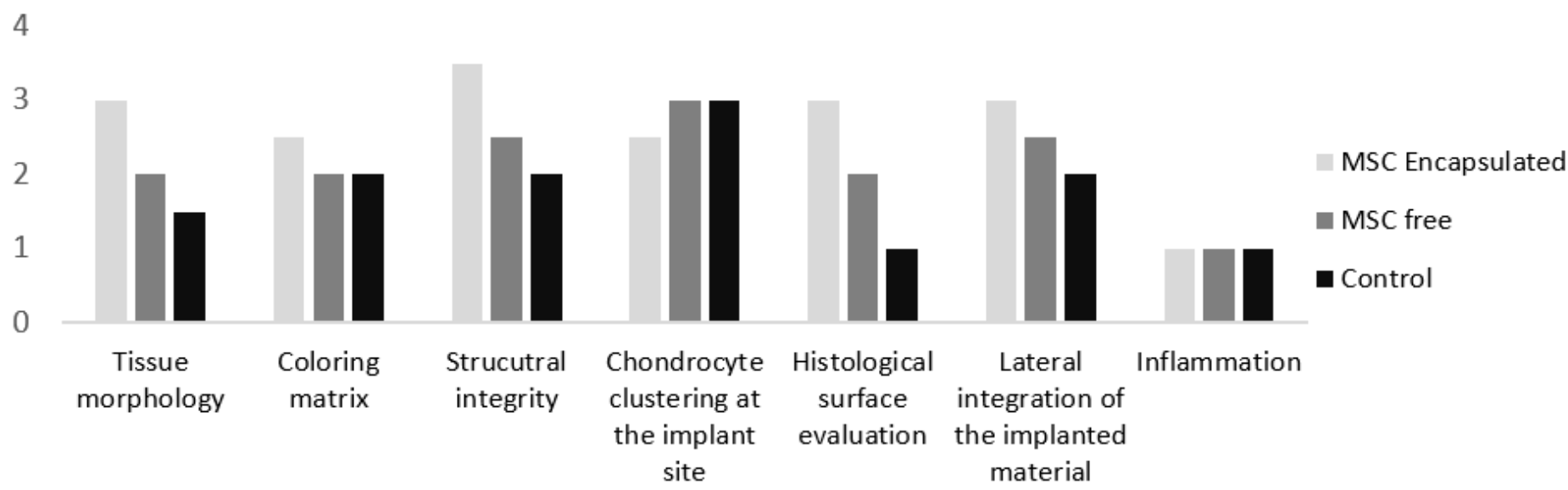

\section{Figure 10}

Median values of O'Driscoll histological scores and Kruskal-Wallis test at 150 days' time point (* means statistical difference). 